\title{
Incorporating Information Communication Technology Skills in Accounting Education
}

\author{
Mohamad Osmani, Qatar University, Qatar \\ Nitham Hindi, Qatar University, Qatar \\ Vishanth Weerakkody, University of Bradford, UK
}

\begin{abstract}
Information and communications technology (ICT) is widely utilized in the accounting profession and has transformed the accounting functions in business and the role of accountants. Acknowledging the significance of ICT skills in accounting education, many employers and professional associations are calling for integration of accounting curricula with ICT. Therefore, it is vital for potential accounting professionals to be equipped with the most current ICT skills pursued by employers. This study searches the current job market to capture a snapshot of the most in demand graduate skills, in particular, ICT skills. Furthermore, it also lists a number of software systems for accountancy solutions and their supplier firms.
\end{abstract}

\section{KEYWORDS}

Accounting and Finance, Employment, ICT Skills, Learning and Teaching, University

\section{INTRODUCTION}

The accounting profession worldwide has come under close examination due to changing technology and globalization of the world economy. Technology has created competitive pressure within the accounting profession that has led to expectations that accounting graduates should develop nonaccounting skills with increasing importance given to information communication technology skills. Accounting software and computer technology are considered essential to career by accounting graduates and employers (Kavanagh and Drennan, 2008). There is also more focus on technological skills during academic studies in the guidance published by Accounting associations and standard setters including the American Accounting Association (AAA) and the Association to Advance Collegiate Schools of Business (AACSB), and the American Institute of Certified Public Accountants (AICPA) (Willis, 2016). Most organizations now require 'Hybrid Accountant' i.e. combining IT/IS competencies and mainstream accounting capabilities. "Hybrid" accountant blends different skills and knowledge of business management and information management (Ahmed, 2003). Universities across the world are now increasingly conscious of this trend and have been responding with suitable initiatives within the operational framework of degree programmes to develop both the necessary and in-demand interpersonal and applied skills that will make their graduates employable in their chosen field of study. 
Interestingly, the impact of the skills challenge has a different dimension in different parts of the world. While many Western nations are faced with the challenge of too many graduates and too few jobs, Middle East countries are trying to reduce their reliance on foreign nationals by developing more local nationals capable of tackling the highly skilled jobs in fields such as accounting and finance and information and communication technology. Several countries in the Middle East, including Qatar have initiated national programmes focused on the development of human capital and the movement towards a knowledge economy. To equip graduates with the required skills in all fields including in Accounting and Finance, Qatar's government launched an initiative known as Qatar National Vision 2030 (QNV 2030). The initiative foresees that in the transition towards knowledge-based economy; future economic success will depend increasingly on the ability of the Qatari nationals to deal with an international order that is knowledge-based and extremely competitive. The vision will allow Qatar to develop its human capital as well as provide an effective example of how to re-skill workforce with up-to-date skills and competencies that will foster analytical and critical thinking as well as creativity and innovation to cater to the changing and complex needs of industry and commerce. In order to achieve sustainable development and maximise the success of related supportive initiatives, it is necessary to start at least from a graduate education perspective. The starting point is therefore a deeper understanding of the gaps and needs that affect the present settings of the graduate education system as well as graduate attributes when analysed against the skills and competencies demanded by employers. As this study is focusing on the importance of ICT skills in accounting education, it is vital to understand the current trends in the field and examine the job market to recognize if ICT skills is one the main areas that are required from accounting graduates. This study will be the first attempt to profile the use of ICT in accounting from a general perspective as well as from a GCC perspective. Given the significance of the finance and accounting profession in Qatar, this paper seeks to capture an overview of the accounting job market and current accounting software solution development. The remainder of the paper is organized as follows. The next section reviews existing literature on ICT skills in accounting education. Thereafter, it highlights the importance and the requirement of ICT Skills in Accounting Job Advertisements and then it identifies the current software's that are in use by accounting firms. Finally, it presents the discussion and conclusion section that outlines the findings and implications of this study.

\section{THE ROLE OF ICT SKILLS IN ACCOUNTING EDUCATION}

In the current business environment, Information and Communication Technology (ICT) skills are given prominence by several authors who identify competency in using various applications and tools as an important strategic differentiator for potential accounting and finance graduate-employees. Technological skills reflect graduates' ability to select and use appropriate technology to address diverse tasks and problems in their work environment (Jackson, 2014a, 2014b). The ability to use common software applications used in accounting and finance is an obvious skill that employers look for in graduates. Cox et al. (2013) offer a more streamlined understanding of it, as graduates' expertise in effectively using ICT, and describing the IS and ICTs of core relevance to understand their practical application. Graduates' ability to adapt to technology is also defined as their ability to use current technology, to be able to learn, and be capable of solving the problem at hand. Employers often highly value technical field-specific knowledge (Hernández-March et al., 2009). Literature argues that most graduates lack the necessary computing skills required by the employers, and these graduates suffer from poor perceptions of the skills expected at the workplace (Gibbs et al., 2011; Gaviria et la., 2015; Ezeani \& Akpotohwo, 2014). While some studies recommend joint efforts from universities and companies in technology transfer agreements to lessen the gap between higher education and labor market requirements (Hernández-March et al., 2009; Ogundana et al., 2015), others suggest that graduates should receive formal tuition to improve their technological skills to prosper at work (Gibbs et al., 2011). Ragland and Ramachandran (2014) investigated the Excel functions that 
are perceived to be important and useful for accounting graduates prior to starting a job in public accounting. The results suggest that accounting students underestimate the importance and usage of some of these Excel functions. Their results also suggest that new hires' perceived knowledge on how to use specific Excel functions in their accounting job is statistically different than students' perceived knowledge on how to use some of the same Excel functions. Willis (2016) also mentioned that excel is an essential skill used in the accounting field and prospective employers value new hires who possess knowledge of this software.

Spraakman et al. (2015) consulted chief financial officers in New Zealand's largest firms and explored their perceptions regarding the IT competencies required of management accounting graduates. Their study identified Excel for analysis as the most important followed by Word, PowerPoint and Outlook. Elsaadani (2015) evaluated the sufficiency of ICT skills of fresh accounting graduates in Egypt and revealed that they should be literate with Internet, word processing software, spreadsheet software, e-mail, commercial accounting software, and database management software. Elsaandi also calls accounting higher education institutions worldwide to keep exploring the requirements of the profession in order to equip graduates with competencies that are demanded by employers. Seethamraju (2010) argued that whether it is auditing, financial accounting or management accounting, relevant information technology skill need to be embedded in the accounting context and train graduates with the help of modern pedagogy. He further argued that many units within accounting courses employ Excel, however, the level of expertise taught is restricted with hardly any university teaching students advanced features such as macros, and other aspects. Tanaka and Sithole (2015) examined the IT skills employer's need and their level of satisfaction with new accounting graduates using survey research. Results of the survey research suggest that students are better trained in word-processing and knowledge of communications software skills, yet employers expect entry level accounting graduates to possess accounting packages knowledge and spreadsheet competencies. The way to address the IT skills deficiencies would require accounting instructors to incorporate advanced excel skills, the teaching of widely used accounting packages.

Senik et al. (2013) explored the expectation gap in information technology (IT) skills development in an accounting degree course in the UK using grounded theory methodology. The findings indicate that some of the required understanding and skills relating to accounting, tax and auditing software is lacking, suggesting an expectation gap. Different opinions concerning who should assume the responsibility for the development of the IT skills of the graduates; the understanding concerning the nature of IT skills; unclear expectations; and a lack of communication among stakeholders in accounting education are the factors perceived to cause the existence of such a gap. According to Chang and Hwang (2003), many in the accounting profession have raised concerns over whether university curriculum courses effectively and efficiently prepare accountants to meet these challenges. Their findings highlighted that educators recognize the importance of IT topics, but educators have difficulty covering all the important IT topics in accounting curricula. To overcome this challenge, accounting firms need to work closely with academicians to find ways to collaborate in teaching the subjects that bring a higher payoff for the resources invested by both colleges and accounting firms.

\section{DEMAND FOR ICT SKILLS IN ACCOUNTING JOB ADVERTISEMENTS}

Many online recruitment sites were searched for accounting related jobs in Qatar; the main purpose of this was to identify the graduate attributes in particular ICT skills listed under these advertised job positions. These sites included Gulftalent, Monstergulf, Naukrigulf, Bayt, and Jobs in Qatar. This study was carried out in the May of 2016, and 21 Accounting related positions were retrieved. The results were based on the jobs posted in the last four weeks of May 2016. The short listed vacancies were observed for their required graduate attributes in particular ICT skills. The findings revealed that whether it is cost accounting, Auditing, Finance director or credit analyst, employers require ICT skills from accounting candidates. 
Table 1. In demand skills in accounting professional

\begin{tabular}{|c|c|}
\hline Position & Skills \\
\hline $\begin{array}{l}\text { Manager of Cost } \\
\text { Accounting }\end{array}$ & $\begin{array}{l}\text { 1) Knowledge of accounting field; 2) Strong people management skills; 3) Time management } \\
\text { skills; 4) Accuracy and attention to detail; 5) Advanced numerical and analytical skills; 6) } \\
\text { Excellent negotiation skills; 7) Excellent report writing skills; 8)Good communication Skills; } \\
\text { 9) Good presentation skills; 10) Advanced MS office skills. }\end{array}$ \\
\hline $\begin{array}{l}\text { Senior Manager IT } \\
\text { Audit - Banking }\end{array}$ & $\begin{array}{l}\text { 1) Be a specialist ICT Auditor; 2) Self- starter; 3) Able to execute audit plan individually 4) } \\
\text { Team working skills; 5) Leadership Skills 6) Strong knowledge of ICT audit methodologies; } \\
\text { 7) Familiar with corporate, treasury and retail lending products }\end{array}$ \\
\hline $\begin{array}{l}\text { Senior Finance } \\
\text { Manager/ Finance } \\
\text { Director }\end{array}$ & $\begin{array}{l}\text { 1) Leadership skills; 2) Management experience; 3) Regional experience; 4) Experience } \\
\text { working within heavy industry; 5) Excellent ICT skills }\end{array}$ \\
\hline Chief Internal Auditor & $\begin{array}{l}\text { 1) Leadership Skills; 2) Accuracy; 3) Presentation skills; 4) Management skills; 5) } \\
\text { Good Reporting skills; 6) Industrial experience; 7) Regional experience; 8) Information } \\
\text { Technology skills; 9) Minimum of a BA Honors Degree; 10) CIA Qualified }\end{array}$ \\
\hline Payroll Accountant & $\begin{array}{l}\text { 1) English Language; 2) Accounting principles; 3) Payroll accounting; 4) Knowledge } \\
\text { of policy and procedure; 5) Time Management; 6) Business Sills and understanding; } \\
\text { 7) Financial awareness; 8) Data gathering and analysis using computing software; 9) } \\
\text { Performance management; 10) Written communication; 11) Financial Accounting; 12) } 6 \\
\text { to } 7 \text { years' experience in Accounts; 13) Bachelor's degree in Accounting or Finance; 14) } \\
\text { Industrial experience }\end{array}$ \\
\hline Finance Manager & $\begin{array}{l}\text { 1) Fluency in English; 2) Excellent commercial experience in the management of large } \\
\text { budgets and projects; 3) Good IT skills with knowledge of Microsoft office packages; 4) } \\
\text { Ability to work independently; 5) Ability to lead; coach and develop a team; 6) Finance } \\
\text { degree level qualification; 7) Must be a Qualified Accountant (ACA; ACCA; or CPA); 8) } \\
\text { Must have experience of in the Middle East }\end{array}$ \\
\hline Accountant & $\begin{array}{l}\text { 1) Ability to analyse issues and recommends solutions; 2) Ability to communicate effectively; } \\
\text { 3) Knowledgeable of accounting systems; 4) Ability to multi-task to meet deadlines in a } \\
\text { timely manner; 5) Strong interpersonal skills; 6) Demonstrates flexibility with changing } \\
\text { priorities; 7) Excellent in Account Package ' Tally ERP' and good exposure in MS Excel; } \\
\text { Word; 8) Bachelor's degree in Accounting; Finance; or any related field; 9) At least } 5 \text { years } \\
\text { of experience; 10) Experience in Construction and GCC is must }\end{array}$ \\
\hline Senior Credit Analyst & $\begin{array}{l}\text { 1) Good Knowledge of banking processes and products; 2) Good knowledge of banking } \\
\text { industry; credit function and regulatory guidelines; 3) Very good computer skills; particularly } \\
\text { Excel and internet search; 4) Sound knowledge of lending practices / systems; credit } \\
\text { policy; risk management; procedures; control procedures; understanding of legal issues } \\
\text { related to lending; 5) Credit market awareness; 6)Good level of analytical skills; 7) Good } \\
\text { communication Skills; 8) Management/supervision skills; 9) University Graduate in Finance } \\
\text { / Accounting / Commerce; 10) Credit training in a reputable financial institution; 11) 5-6 } \\
\text { years' experience in similar role and } 6 \text { years in a banking/finance environment; }\end{array}$ \\
\hline $\begin{array}{l}\text { Accounts / } \\
\text { Administration } \\
\text { Assistant }\end{array}$ & $\begin{array}{l}\text { 1) Numerical ability; 2) Attention to detail; 3) Professional manner; 4) Strong organisational } \\
\text { and planning skills; 5) Ability to work on own initiative and with minimum supervision; 6) } \\
\text { Good communication skills both verbal and written; 7) Good ICT skills }\end{array}$ \\
\hline $\begin{array}{l}\text { Finance Supervisor - } \\
\text { Accounts Receivable }\end{array}$ & $\begin{array}{l}\text { 1) Strong computer skills with knowledge of Oracle Financials; 2) Fluent with excellent command } \\
\text { in English; 3) Excellent communication 4) Presentation skills 5) Ability to work effectively in a } \\
\text { multi-cultural environment; 6) Bachelor's degree; 7) } 3 \text { years job-related experience }\end{array}$ \\
\hline $\begin{array}{l}\text { Finance Supervisor - } \\
\text { Credit Card Processing }\end{array}$ & $\begin{array}{l}\text { 1) Good knowledge in computer applications; including Microsoft Excel; Word and Power point; } \\
\text { 2) User level experience in any ERP system; 3) Strong knowledge in complete interline billing } \\
\text { process in passenger revenue accounting; 4) Excellent knowledge of Airline Business including } \\
\text { understanding of Operational aspect and business flow; 5) Fluent with excellent command in } \\
\text { English; 6) Bachelor degree in Accounting/Commerce; 7) } 3 \text { years of job-related experience }\end{array}$ \\
\hline
\end{tabular}


Table 1. Continued

\begin{tabular}{|c|c|}
\hline Position & Skills \\
\hline $\begin{array}{l}\text { Officer Merchant } \\
\text { E-Acquiring }\end{array}$ & $\begin{array}{l}\text { 1)Educated to degree level; 2) Strong ICT skills required; 3) Experience of developing new } \\
\text { products to grow the merchant acquiring business (such as DCC or Contactless payment) }\end{array}$ \\
\hline $\begin{array}{l}\text { Senior Investment } \\
\text { Accountant }\end{array}$ & $\begin{array}{l}\text { 1) Deliver on time; 2) Knowledge sharing skills; 3) Organizing skills; 4) ICT skills; 5) } \\
\text { Professional Certification such as ACCA; CPA; CIMA; 6) } 6 \text { years in Accounting with } \\
\text { experience in investment accounting }\end{array}$ \\
\hline $\begin{array}{l}\text { Assurance - Senior } \\
\text { Associate - Financial } \\
\text { Services }\end{array}$ & $\begin{array}{l}\text { 1) Problem solving and delivering client solutions; 2) Experience of working on audits; 3) } \\
\text { Audit management experience; 4) Experience of interacting with senior level clients and } \\
\text { management; 5) Effective communication skills; 6) Team working skills; 7) ICT skills; } \\
\text { 8) Ability to take responsibility and use initiative; 9) Ability to work independently; 10) } \\
\text { Experience in supervising and developing staff; 11) Knowledge of IAS and IFRS }\end{array}$ \\
\hline $\begin{array}{l}\text { Senior Project Financial } \\
\text { Controller }\end{array}$ & $\begin{array}{l}\text { 1) Analytical skills; 2) IT skills, specifically very strong excel skills; 3) Confident and self- } \\
\text { assured to be able deal with senior project leaders; 4) Ability to present an objective opinion; } \\
\text { 5) Commercially aware; 6) Able to build relationships; 7) Professional working approach; 8) } \\
\text { Excellent communication and literacy skills; 9) Good work ethic and keenness to improve }\end{array}$ \\
\hline Group CFO & $\begin{array}{l}\text { 1) Leadership skills 2) Ability to influence senior management / executives; 3) Excellent ICT } \\
\text { skills; 4) Strong Character; 5) Highly qualified CFO; 6) Experience in a similar role }\end{array}$ \\
\hline $\begin{array}{l}\text { Manager; Deal } \\
\text { Advisory (Infrastructure } \\
\text { and Financing) }\end{array}$ & $\begin{array}{l}\text { 1) Detailed knowledge of project financing; 2) Financial modelling skills; 3) Excellent } \\
\text { analytical skills; 4) Interpersonal skills; 5) ICT skills; 6) Communication skills; both written } \\
\text { and verbal; 7) Strong work initiative; 8) Ability to adapt to new challenges and ideas; 9) } \\
\text { Experience of managing transactions; 10) Strong academic record including a post graduate } \\
\text { degree from a reputed institution }\end{array}$ \\
\hline Senior Accountant & $\begin{array}{l}\text { 1) Management of team; 2) Good communication; 3) Leadership skills; 4) ICT Skills; 5) } \\
\text { Professional qualification such as CPA or CFA; 6) } 2 \text { years finance experience }\end{array}$ \\
\hline Internal Auditor & $\begin{array}{l}\text { 1) Strong analytical skills; 2) Communication skills; both written \& verbal; 3) Presentation } \\
\text { skills; 4) Research skills; 5) Interpersonal skills; 6) Relationship building skills; 7) ICT } \\
\text { skills; 8) Ability to multi-task; 9) Thorough attention to detail; 10) Excellent problem-solving } \\
\text { skills; 11) Ability to work under pressure; 12) Bachelor's degree in accounting or finance and } \\
\text { chartered accountant qualification is preferred; 13) } 6+\text { years of experience in a similar role }\end{array}$ \\
\hline $\begin{array}{l}\text { Operational Auditor - } \\
\text { H\&M Shared Services }\end{array}$ & $\begin{array}{l}\text { 1) Strong analytical skills; 2) High degree of tact; 3) Self-reliance skills; 4) Technical and } \\
\text { ICT skills; 5) Management skills; 6) 4-6 years' experience in operational and financial audits }\end{array}$ \\
\hline Reconciliation Officer & $\begin{array}{l}\text { 1) Banking experience is essential; 2) 2-4 years' experience in a relevant role; 3) University } \\
\text { degree level qualified; 4) Experience working with banking IT systems is a key element of } \\
\text { this role; 5) The successful candidate must also be capable of meeting tight deadlines and } \\
\text { working under pressure; 6) Experience working with ATM functions and credit cards }\end{array}$ \\
\hline
\end{tabular}

\section{SOFTWARE SYSTEMS FOR ACCOUNTANCY PROFESSIONS}

There are a number of commercial software systems available in the market that provide:

- A cashbook for business users;

- Complete double entry bookkeeping for both business users and their accountants;

- Accounting software with integrated payroll;

- Accounts production for accountants in practice to produce periodic financial statements for their clients from their manual or computerised accounting records;

- Software for specific market segments;

- Customer relationship management (CRM) software for managing clients, billing and marketing. 
Table 2. List of accounting software providers

\begin{tabular}{|c|c|}
\hline $\begin{array}{l}\text { Software Provider With } \\
\text { URL }\end{array}$ & Description \\
\hline $\begin{array}{l}\text { Absolute Accounting } \\
\text { Software Ltd www. } \\
\text { absolutetax.co.uk }\end{array}$ & $\begin{array}{l}\text { The company has various software solutions to meet the requirements of sole practitioners } \\
\text { to multi office firms of Accountants. This is both in a fully integrated package, to a } \\
\text { comprehensive tax program, Topup tax, which allows users to continue with their existing } \\
\text { Accounts software. }\end{array}$ \\
\hline $\begin{array}{l}\text { Accounts anywhere www. } \\
\text { accountsanywhere.co.uk }\end{array}$ & $\begin{array}{l}\text { Accounts Anywhere are a secure online accountancy service available to businesses and } \\
\text { their accountants over the internet. Now available free for the first year to new businesses. }\end{array}$ \\
\hline $\begin{array}{l}\text { Accounts IQ } \\
\text { www.accountsiq.com }\end{array}$ & $\begin{array}{l}\text { Designed for the cloud, AccountsIQ is unique in providing Accounting, Consolidation and } \\
\text { Business Intelligence in one powerful solution. } \\
\text { This makes it ideal for high potential Start-ups, multi-subsidiary groups, multi-site } \\
\text { businesses such as retailers, distributors, franchises, large charities and their accountants. }\end{array}$ \\
\hline $\begin{array}{l}\text { AccountsPortal www. } \\
\text { accountsportal.com }\end{array}$ & $\begin{array}{l}\text { AccountsPortal makes it easy to manage your } \\
\text { invoicing, books and accounts. Web-based accounting software that is easy to use, } \\
\text { intuitive and flexible. Used by contractors, freelancers, small businesses, bookkeepers and } \\
\text { accountants to manage their books from anywhere. }\end{array}$ \\
\hline Aplicor www.aplicor.com & $\begin{array}{l}\text { Aplicor is an easy-to-use software suite that includes ERP, CRM and ECommerce } \\
\text { applications. At every step from suppliers through happy customers, you can trust } \\
\text { everything in your business is running smoothly - anytime and anywhere. }\end{array}$ \\
\hline Aqilla www.aqilla.com & $\begin{array}{l}\text { Developer of web-based accounting solutions designed for medium-sized businesses and } \\
\text { organisations. API and plugins ensure easy integration into CRM, Business Intelligence, } \\
\text { Excel and other backend systems. }\end{array}$ \\
\hline $\begin{array}{l}\text { Brightpearl www. } \\
\text { brightpearl.co.uk }\end{array}$ & $\begin{array}{l}\text { Inventory Management and Real-time Accounting for Omni-channel Retailers. Powerful, } \\
\text { integrated, retail management software proven to help retailers be more profitable. } \\
\text { Inventory, orders, customers and finances in a single system. }\end{array}$ \\
\hline $\begin{array}{l}\text { BTC Software www. } \\
\text { btcsoftware.co.uk }\end{array}$ & $\begin{array}{l}\text { The company offers Accountancy Practice Management software that allows the user to be } \\
\text { in full control of accounting in the organisation. }\end{array}$ \\
\hline $\begin{array}{l}\text { Capium www.capium. } \\
\text { com }\end{array}$ & $\begin{array}{l}\text { Capium's easy to use services make it a complete package that makes life easier for } \\
\text { accountants, small and medium sized businesses. No matter if you do not have any } \\
\text { accounting or bookkeeping knowledge, Capium works in a way where you can get going } \\
\text { quickly. }\end{array}$ \\
\hline $\begin{array}{l}\text { CaseWare www.caseware. } \\
\text { co.uk }\end{array}$ & $\begin{array}{l}\text { Established for over } 20 \text { years and operating in } 130 \text { countries, CaseWare's best of breed } \\
\text { solutions provide reliability and flexibility to accountants in practice or business. In the } \\
\text { UK, CaseWare products are used by four of the top five accountancy firms and around } \\
\text { half of the Top } 100 \text { Practices, in addition to a multitude of mid-tier practices and sole } \\
\text { practitioners. CaseWare software is also widely used throughout the corporate sector for } \\
\text { the preparation of final accounts and corporation tax filings. }\end{array}$ \\
\hline $\begin{array}{l}\mathrm{CCH} \text { (brand of Wolters } \\
\text { Kluwer www.cch.co.uk }\end{array}$ & $\begin{array}{l}\text { Wolters Kluwer enables tax, finance, compliance, legal and healthcare professionals to be } \\
\text { more effective and efficient. As a market-leading global information services company } \\
\text { with annual revenues of over } € 3.6 \text { billion and operations in over } 40 \text { countries, we provide } \\
\text { information, software and services that deliver vital insights, intelligent tools and the } \\
\text { guidance of subject-matter experts. }\end{array}$ \\
\hline $\begin{array}{l}\text { Clear Books www. } \\
\text { clearbooks.co.uk }\end{array}$ & $\begin{array}{l}\text { Clear Books plc develops clear \& simple cloud accounting and payroll software for small } \\
\text { businesses in the UK. }\end{array}$ \\
\hline $\begin{array}{l}\text { Digita (Thomson Reuters) } \\
\text { www.digita.com }\end{array}$ & $\begin{array}{l}\text { Digita software is developed by the leading provider of technology and information } \\
\text { solutions. Based in Exmouth, UK, Digita's software delivers time saving efficiencies } \\
\text { to over 2,000 tax and accountancy practices in the UK and Ireland. Our } 25 \text { years of } \\
\text { experience in understanding the needs of accountants in practice and ongoing feature } \\
\text { development has made us the software provider of choice for our customers. }\end{array}$ \\
\hline
\end{tabular}


Table 2. Continued

\begin{tabular}{|c|c|}
\hline $\begin{array}{l}\text { Software Provider With } \\
\text { URL }\end{array}$ & Description \\
\hline $\begin{array}{l}\text { e-conomic www.e- } \\
\text { conomic.co.uk }\end{array}$ & $\begin{array}{l}\text { Cloud accounting platform providing efficient online collaboration between small } \\
\text { businesses and accountants. }\end{array}$ \\
\hline $\begin{array}{l}\text { Eureka! Software www. } \\
\text { eureka-software.com }\end{array}$ & $\begin{array}{l}\text { Eureka! Software was formed in } 1982 \text { and is now a well-established international company } \\
\text { with many years' experience in developing software solutions for the Public and Private } \\
\text { Sectors. The company specialises in Flexitime, Time Recording and Accounts Production } \\
\text { software. }\end{array}$ \\
\hline $\begin{array}{l}\text { FinancialForce www. } \\
\text { financialforce.com }\end{array}$ & $\begin{array}{l}\text { Founded in 2009, FinancialForce is the leading Cloud ERP vendor with apps built entirely } \\
\text { on the Salesforce App Cloud. The company's Financial Management, Professional Services } \\
\text { Automation (PSA), and Human Capital Management (HCM) offerings provide services- } \\
\text { centric businesses with a platform that organizes sales, services, finance and HR entirely } \\
\text { around their customers. }\end{array}$ \\
\hline $\begin{array}{l}\text { FreeAgent Central www. } \\
\text { freeagentcentral.com }\end{array}$ & $\begin{array}{l}\text { FreeAgent provides online accounting software made specifically for freelancers, small } \\
\text { business owners and their accountants. }\end{array}$ \\
\hline $\begin{array}{l}\text { gbooks www.gbooks. } \\
\text { co.uk }\end{array}$ & $\begin{array}{l}\text { gbooks uses the latest technologies to make the tax and accounts compliance process as } \\
\text { smooth and efficient as possible. gbooks also includes a range of practice management } \\
\text { tools to help you manage your practice and staff more profitably. Being fully online, there } \\
\text { are no discs to install or networks to run, saving you time and money. }\end{array}$ \\
\hline IRIS http://www.iris.co.uk & $\begin{array}{l}\text { With } 37 \text { years' experience, IRIS is the UK's market leading provider of business-critical } \\
\text { software and services to the UK accountancy and payroll sectors. IRIS continues to be the } \\
\text { leading supplier to the UK accountancy sector with over 17,000 Accountancy Practices } \\
\text { relying on IRIS every day to run their business, and IRIS meets the needs of over } 80,000 \\
\text { SMEs through its leading bookkeeping, payroll and HR software solutions. Today our } \\
\text { customers choose to consume our award-winning products installed on their desktops, as } \\
\text { services from the cloud, or a combination of both. }\end{array}$ \\
\hline $\begin{array}{l}\text { JustAccounts www. } \\
\text { justaccounts.com }\end{array}$ & $\begin{array}{l}\text { JustAccounts is a UK based company, offering an integrated platform that enables UK } \\
\text { Contractor Accountants to provide client-facing solutions with powerful efficiency and } \\
\text { efficacy. }\end{array}$ \\
\hline $\begin{array}{l}\text { KashFlow www.kashflow. } \\
\text { co.uk }\end{array}$ & $\begin{array}{l}\text { Since 2005, KashFlow has been providing intuitive online accounting software for small } \\
\text { business owners. In 2013, KashFlow was acquired by IRIS. }\end{array}$ \\
\hline $\begin{array}{l}\text { Keytime www.keytime. } \\
\text { co.uk }\end{array}$ & $\begin{array}{l}\text { The company has been providing software to accountants for more than } 25 \text { years, and } \\
\text { claims to sell the best value integrated software on the market today. The company claims } \\
\text { that they are the only supplier to accountants who publish live satisfaction rating, and we } \\
\text { are honoured to have the trust of over } 1,700 \text { practices. }\end{array}$ \\
\hline $\begin{array}{l}\text { KPMG www.kpmg.com/ } \\
\text { uk/trinity }\end{array}$ & $\begin{array}{l}\text { KPMG has developed K-Trinity Accounts Production to tackle the frustrations finance } \\
\text { teams experience preparing statutory accounts in Word or Excel including manual data } \\
\text { entry, last minute adjustments and rounding errors. }\end{array}$ \\
\hline $\begin{array}{l}\text { Liberty Accounts www. } \\
\text { libertyaccounts.com }\end{array}$ & Online accounting and payroll software for British business. \\
\hline $\begin{array}{l}\text { Liquid Accounts www. } \\
\text { liquidaccounts.net }\end{array}$ & $\begin{array}{l}\text { Liquid's online accounting software makes doing your books easy by automating painful } \\
\text { tasks, integrating multiple business systems and allowing you to run your business on the } \\
\text { go. }\end{array}$ \\
\hline $\begin{array}{l}\text { Mamut Software Ltd. } \\
\text { www.mamut.com/uk }\end{array}$ & $\begin{array}{l}\text { Mamut One Office and Enterprise is a complete and flexible ERP system. The product } \\
\text { series cover the total needs of small and mid-sized businesses with single or multiple users } \\
\text { at an affordable price. }\end{array}$ \\
\hline
\end{tabular}




\begin{tabular}{|c|c|}
\hline $\begin{array}{l}\text { Software Provider With } \\
\text { URL }\end{array}$ & Description \\
\hline $\begin{array}{l}\text { MyBusiness www.mybiz. } \\
\text { co.uk }\end{array}$ & $\begin{array}{l}\text { MyBusiness accounting software for small business is not only easy to use bookkeeping } \\
\text { software but it also provides powerful accounting features and provide the information } \\
\text { needed for end of year accounts preparation. MyBusiness accounting software has been } \\
\text { around for } 10 \text { years and was designed and developed with small businesses in mind. }\end{array}$ \\
\hline $\begin{array}{l}\text { Netsuite www.netsuite. } \\
\text { co.uk }\end{array}$ & $\begin{array}{l}\text { NetSuite is the leading integrated cloud business software suite, including business } \\
\text { accounting, ERP, CRM and ecommerce software. On July 28, 2016, Oracle announced that } \\
\text { it entered into a definitive agreement to acquire NetSuite. }\end{array}$ \\
\hline $\begin{array}{l}\text { Pinacle Accounts www. } \\
\text { pinacleaccounts.co.uk/ }\end{array}$ & $\begin{array}{l}\text { Pinacle is a full suite of accountant's software, which integrates accountancy practice } \\
\text { data in a single Oracle }{ }^{\mathrm{TM}} \text { client database. Applications include final accounts generation, } \\
\text { taxation, practice management, bureau payroll and book-keeping. }\end{array}$ \\
\hline $\begin{array}{l}\text { Quickbooks www. } \\
\text { quickbooks.co.uk }\end{array}$ & $\begin{array}{l}\text { Accounting software that helps you create custom invoices, manage VAT and see your data } \\
\text { in real time. Our software and services help business owners get on top of their finances, } \\
\text { accounts, payroll and payments, faster. }\end{array}$ \\
\hline $\begin{array}{l}\text { Relate www.relate- } \\
\text { software.com }\end{array}$ & $\begin{array}{l}\text { Specialising in the Areas of Practice Management, Accounts Production, Company } \\
\text { Secretarial, Personal Tax and Corporation Tax. All products work independently or as one } \\
\text { fully integrated suite. }\end{array}$ \\
\hline Sage http://sage.co.uk/ & $\begin{array}{l}\text { Sage is the market leader for integrated accounting, payroll and payment systems, } \\
\text { supporting the ambition of the world's entrepreneurs. Today over 13,000 colleagues at } \\
\text { SAGE support millions of entrepreneurs across } 23 \text { countries. }\end{array}$ \\
\hline $\begin{array}{l}\text { SAP Business By } \\
\text { Design www.sap.com/ } \\
\text { BusinessByDesign }\end{array}$ & $\begin{array}{l}\text { Ideally suited for upper mid-market companies and subsidiaries of large corporations, } \\
\text { this complete and integrated SaaS suite supports financials, human resources, sales, } \\
\text { procurement, customer service, supply chain management. }\end{array}$ \\
\hline $\begin{array}{l}\text { TaxCalc www.taxcalc. } \\
\text { com }\end{array}$ & $\begin{array}{l}\text { For over } 10 \text { years, the company has been supporting taxpaying individuals, business } \\
\text { owners and accountancy practices with a comprehensive and modern range of software. }\end{array}$ \\
\hline $\begin{array}{l}\text { Twinfield www.twinfield. } \\
\text { co.uk }\end{array}$ & $\begin{array}{l}\text { Twinfield UK is part of the Wolters Kluwer Tax \& Accounting division, the global leading } \\
\text { provider of tax, accounting and audit information, software and services. Originating in } \\
\text { The Netherlands, Twinfield has grown to be the European market leader in the area of } \\
\text { online accounting. }\end{array}$ \\
\hline VT www.vtsoftware.co.uk & $\begin{array}{l}\text { VT is well known for its inexpensive and easy to use accounts production and bookkeeping } \\
\text { software. The packages are widely used, especially by smaller firms of accountants and } \\
\text { their clients. A free cash book package is also available. }\end{array}$ \\
\hline $\begin{array}{l}\text { WinWeb www.winweb. } \\
\text { com }\end{array}$ & $\begin{array}{l}\text { Since } 1994 \text { WinWeb, a leading cloud computing software provider, has been helping } \\
\text { SMEs/SMBs to run their businesses securely online and adapt to the changing world of } \\
\text { online commerce, social media and globalisation. }\end{array}$ \\
\hline Xero www.xero.com & $\begin{array}{l}\text { Xero is a New Zealand-based software company that develops cloud-based accounting } \\
\text { software for small and medium-sized businesses. The company has offices in New Zealand, } \\
\text { Australia, the United Kingdom, the United States and Singapore. Use Xero accounting } \\
\text { software to manage invoicing, bank reconciliation, bookkeeping. }\end{array}$ \\
\hline
\end{tabular}

The software for accountancy solutions has been generally provided by a small number of well-established suppliers. However, in the last 5 years a number of smaller software vendors have established themselves in this fast-moving industry. Table 2 lists a number of established and newcomers here in alphabetical order (please note that this is a non-exhaustive list, however, most of the major players are listed). 


\section{DISCUSSION AND CONCLUSION}

In this study, we look at existing literature, the major providers of accounting software, main software products available in the market, learning opportunities on software, and the latest trends in ICT and Accountancy profession. The findings showed that whether it is cost accounting, Auditing, Finance director or credit analyst, employers require ICT skills from accounting candidates. This study also found that the accountancy profession is changing fast and organizations are increasingly using software for their accounting and finance requirements. In addition, software vendors are increasingly balancing their offerings based on either desktop-based software and/or online software. This study also discovered that the next major development is the move towards online software. Online or cloud-based accounting software is enabling small companies to do bookkeeping tasks themselves thereby significantly reducing costs. Another trend in this industry is the use of data-analytics, for e.g. auditors are now able to verify complete sets of data rather than small samples and at the same time reduce human errors. Vendors that provide web-based solutions are seeing an increase in their business. For example, Sage Software in the Middle East is very famous among businesses, which provides a range of business intelligence, finance, accounting and bookkeeping software solutions. Both these trends highlight that non-accounting professionals could perform a number of tasks that were historically confined to the accountancy professionals. And at the same time, accountancy professionals need to learn new software to make their services more attractive to businesses. To do so, employers need to be involved with educational institutions to form partnerships, which would help develop a curriculum that defines the required necessary technical and soft skills for graduates' future career paths. In addition, employers should collaborate with universities to develop training courses, work placement clubs, career advice clubs and apprenticeships courses, which would enhance graduates' skills and make them work ready. To make a success of Qatar's nationalization program, government should collaborate with both employers and universities to design a curriculum, which delivers skilled graduates.

\section{ACKNOWLEDGMENT}

This publication was made possible by NPRP grant \# [7-1534- 5-231] from the Qatar National Research Fund (a member of Qatar Foundation). The findings achieved herein are solely the responsibility of the author[s]. 


\section{REFERENCES}

Ahmed, A. (2003). The level of IT/IS skills in accounting programmes in British universities. Management Research News, 26(12), 20-58. doi:10.1108/01409170310783709

Chang, C.J. \& Hwang, N.C.R. (2003). Accounting education, firm training and information technology: A research note. Accounting Education, 12(4), 441-450. doi:10.1080/0963928032000065557

Cox, A.M., Al Daoud, M., \& Rudd, S. (2013). Information management graduates' accounts of their employability: a case study from the University of Sheffield. Education for Information, 30(1, 2), 41-61.

Elsaadani, M. (2015). Information and communication technology skills' sufficiency of Egyptian accounting graduates. International Journal of Advanced Information Technology, 5(1/2), 1-11. doi:10.5121/ijait.2015.5201

Ezeani, N. S., \& Akpotohwo, F. C. (2014). Integrating information and communication technology (ICT) in accounting education instruction in Ekiti State Universities. International Journal of Business and Social Science, 5(6), 1.

Gaviria, D., Arango, J., \& Valencia, A. (2015). Reflections about the use of information and communication technologies in accounting education. Procedia: Social and Behavioral Sciences, 176, 992-997. doi:10.1016/j. sbspro.2015.01.569

Gibbs, S., Steel, G., \& Kuiper, A. (2011). Expectations of Competency: The Mismatch between Employers' and Graduates' Views of End-User Computing Skills Requirements in the Workplace. Journal of Information Technology Education: Research, 10(1), 371-382. doi:10.28945/1531

Hernández-March, J., Martín del Peso, M., \& Leguey, S. (2009). Graduates' skills and higher education: The employers' perspective. Tertiary Education and Management, 15(1), 1-16. doi:10.1080/13583880802699978

Jackson, D. (2014a). Testing a model of undergraduate competence in employability skills and its implications for stakeholders. Journal of Education and Work, 27(2), 220-242. doi:10.1080/13639080.2012.718750

Jackson, D. (2014b). Modelling graduate skill transfer from university to the workplace. Journal of Education and Work, 1-33.

Kavanagh, M. H., \& Drennan, L. (2008). What skills and attributes does an accounting graduate need? Evidence from student perceptions and employer expectations. Accounting and Finance, 48(2), 279-300. doi:10.1111/ j.1467-629X.2007.00245.x

Ogundana, O. M., Ibidunni, A. S., \& Jinadu, O. (2015). ICT integration in accounting education: Evidence from two private higher institutions in Nigeria. Acta Universitatis Danubius Communicatio, 9(2).

Ragland, L., \& Ramachandran, U. (2014). Towards an understanding of excel functional skills needed for a career in public accounting: Perceptions from public accountants and accounting students. Journal of Accounting Education, 32(2), 113-129. doi:10.1016/j.jaccedu.2014.03.002

Seethamraju Dr, R. (2010). Information technologies in Accounting education. Retrieved from http://aisel. aisnet.org/siged2010/12

Senik, R., Broad, M., Mat, N., \& Kadir, S. A. (2013). Information technology (IT) knowledge and skills of accounting graduates. Jurnal Pengurusan, 38, 87-100. doi:10.17576/pengurusan-2013-38-08

Spraakman, G., O’Grady, W., Askarany, D., \& Akroyd, C. (2015). Employers' perceptions of information technology competency requirements for management accounting graduates. Accounting Education, 24(5), 403-422. doi:10.1080/09639284.2015.1089177

Tanaka, S., \& Sithole, M. (2015). Information Technology Knowledge and Skills Accounting Graduates Need. International Journal of Business and Social Science, 6(8), 47-52.

Willis, V. F. (2016). A model for teaching technology: Using Excel in an accounting information systems course. Journal of Accounting Education, 36, 87-99. doi:10.1016/j.jaccedu.2016.05.002 
Mohamad Osmani is a Research Fellow at the College of Business and Economics, Qatar University. His research interest is focused on public management, public sector digital transformation, public value of digital government, graduates employability and management education. He has published a number of peer-reviewed articles in leading journals on these themes. He is managing editor for the International Journal of Electronic Government Research (IJEGR) and is also member of editorial advisory board of the Transforming Government: People, Process \& Policy (TGPPP) journal.

Nitham M. Hindi is an Accounting Professor and an Associate Vice President for Academic Planning and Development, Qatar University. He has published in the areas of financial accounting, banking, cost accounting, and management education. His published work can be found in the Journal of Computer Information Systems, the Journal of Accounting and Finance Research, the Journal of Education for Business, the Journal of Bank Taxation, Global Business and Finance Review, the Journal of Information Systems Education, the Review of Business Information Systems, and Studies in Business and Economics.

Vishanth Weerakkody is a Professor in Management Information Systems and Governance at the School of Management, University of Bradford, UK. His current research is focused on skills and capacity building, social innovation, digital governance, ICT adoption and diffusion, digital inclusion, process transformation and change and innovation and knowledge management in the public sector. He has published over 100 peer-reviewed articles, guest-edited special issues of leading journals and edited several books on these themes. He has many years of $R \& D$ experience in the field of e-government and is currently an investigator in several European Commission and internationally funded projects. 